doi: https://doi.org/10.15407/microbiolj83.06.075

\title{
THE EFFECT OF SURFACTANTS OF MICROBIAL ORIGIN ON PHYTOPATHOGENIC MICROORGANISMS
}

\author{
T.P. Pirog ${ }^{1,2}$, D.V. Piatetska ${ }^{1}$ H.A. Yarova ${ }^{1}$, G.O. Iutynska ${ }^{2}$ \\ ${ }^{1}$ National University of Food Technologies, \\ 68 Volodymyrska Str., Kyiv, 01601, Ukraine \\ ${ }^{2}$ Zabolotny Institute of Microbiology and Virology, NAS of Ukraine, \\ 154 Acad. Zabolotny Str., Kyiv, 03143, Ukraine \\ e-mail:tapirog@nuft.edu.ua
}

Biodegradable non-toxic surfactants of microbial origin are multifunctional preparations, which due to antimicrobial activity are promising for use in crop production to control phytopathogenic microorganisms. Studies on the prospects of using microbial surfactants to control the number of phytopathogenic microorganisms are conducted in three directions: laboratory studies of antimicrobial activity of surfactants in vitro, determination of the effect of surfactants on phytopathogens in vegetative experiments in the process of plants growing in a laboratory or greenhouse, post-harvest treatment of fruits and vegetables with solutions of microbial surfactants to extend their shelf life. The review presents literature data on antimicrobial activity of surfactants against phytopathogenic bacteria and fungi in vitro. Antimicrobial activity of surfactants is evaluated by three main parameters: minimum inhibitory concentration, zones of growth retardation of test cultures on agar media and inhibition of growth of test cultures on agar or liquid media. The vast majority of available publications relate to the antifungal activity of surfactant lipopeptides and rhamnolipids, while data on the effect of these microbial surfactants on phytopathogenic bacteria (representatives of the genera Ralstonia, Xanthomonas, Pseudomonas, Agrobacterium, Pectobacterium) are few. The researchers determined the antimicrobial activity of either total lipopeptides extracted with organic solvents from the culture broth supernatant, or individual lipopeptides (iturin, surfactin, fengycin, etc.) isolated from a complex of surfactants, or culture broth supernatant. Lipopeptides synthesized by members of the genus Bacillus exhibit antimicrobial activity on phytopathogenic fungi of the genera Alternaria, Verticillium, Aspergillus, Aureobasidium, Botrytis, Rhizoctonia, Fusarium, Penicillium, Phytophora, Sclerotinia, Curvularia, Colletotrichum, etc. in sufficiently high concentrations. Thus, the minimum inhibitory concentrations of lipopeptides against phytopathogenic fungi are orders of magnitude higher (in average $0.04-8.0 \mathrm{mg} / \mathrm{mL}$, or $40-8000 \mu \mathrm{g} / \mathrm{mL}$ ) than against phytopathogenic bacteria $(3-75 \mu \mathrm{g} / \mathrm{mL})$. However, the antifungal activity of lipopeptidecontaining supernatants is not inferior by the efficiency to the activity of lipopeptides isolated from them, and therefore, to control the number of phytopathogenic fungi in crop production, the use of lipopeptidecontaining supernatants is more appropriate. Rhamnolipids synthesized by bacteria of the genus Pseudomonas are more effective antimicrobial agents comparing to lipopeptides: the minimum inhibitory concentrations of rhamnolipids against phytopathogenic fungi are 4-276 $\mu \mathrm{g} / \mathrm{mL}$, which is an order of magnitude lower than lipopeptides. In contrast to the data on the antifungal activity of rhamnolipids against phytopathogens, there are only a few reports in the literature on the effect of these surfactants on phytopathogenic bacteria, whilst the minimal inhibitory concentrations are quite high (up to $5000 \mu \mathrm{g} / \mathrm{mL}$ ). The advantage of rhamnolipids as antimicrobial agents compared to lipopeptides is the high level of synthesis on cheap and available in large quantities industrial waste. Currently in the literature there is little information about the effect of surface-active sophorolipids of microbial origin on phytopathogenic fungi, and all these works are mainly about the antifungal activity of sophorolipids. We note that in contrast to surfactant lipopeptides and rhamnolipids, the effective concentration of most sophorolipids, which provides the highest antimicrobial activity against phytopathogens, is higher and reaches $10,000 \mu \mathrm{g} / \mathrm{mL}$.

Keywords: antimicrobial activity, phytopathogenic fungi, phytopathogenic bacteria, lipopeptides, rhamnolipids, sophorolipids. 
Microbial surface-active substances (surfactants) due to their unique physicochemical and biological properties can be used in various industries, such as food, medicine, oil, as well as for environmental cleaning [1-4]. In recent years, there have been reports of the use of surfactants of microbial origin in agriculture [4-6]. In the review [7], we noted that the role of microbial surfactants as plant protection products is due to their use for bioremediation of agricultural soils, pesticide production, control of phytopathogens, participation in plant-microbial interactions and plant growth stimulation.

Studies on the prospects of using microbial surfactants to control the number of phytopathogenic microorganisms are conducted in three directions. The first direction includes laboratory studies of antimicrobial activity of surfactants in vitro with the definition of such indicators as minimal inhibitory concentrations of surfactants, zones of growth retardation of test cultures on agar media and the degree of growth inhibition in the presence of microbial surfactants [8-11]. In the second direction studies, the antimicrobial activity of surfactants is analyzed, treating vegetative plants (or plant seeds) with their solutions in the process of their cultivation in a laboratory or greenhouse [12-15]. The third direction covers work related to post-harvest treatment of fruits and vegetables with solutions of microbial surfactants in order to extend their shelf life (the so-called post-harvest biocontrol of the number of phytopathogens) [10, 16-18].

The vast majority of available literature on the control of the phytopathogens number in the presence of microbial surfactants are complex, as they include studies of antimicrobial activity of surfactants against phytopathogens both in vitro and in vivo [8, 10, 12-15].

It should be noted that literature reviews on this topic, which have appeared in recent years, usually include publications that belong to all three areas of research [6, 7, 19-22]. Besides, such reviews consider, in addition to controlling the number of phytopathogens, other aspects of the impact of microbial surfactants on plant development (participation in the induced plant resistance system; inhibition of zoospores of plant pathogens resistant to commercial chemical pesticides; participation in the formation of biofilms of microorganisms that phytopathogen antagonists, etc.) $[6,7,19-23]$.
The purpose of this review is to analyze and summarize the literature data related to the study of antimicrobial activity against phytopathogenic bacteria and fungi in vitro.

The need to systematize such data is due to the fact that the researcher who studies microbial surfactants and their biological activity, in order to find the necessary information is not always easy to navigate in the works intended for specialists in crop production, in particular, plant-microbial interaction.

The available literature contains information on the action of surface-active lipopeptides [6, 8$11,13,15,19,21-23]$, rhamnolipids [5, 6, 12, $14,23-25]$ and sophorolipids on phytopathogenic microorganisms $[5,26-28]$.

\section{Lipopeptides for controlling the number of phytopathogens}

The first reports of antimicrobial activity of surfactant lipopeptides of microbial origin against phytopathogens appeared in the $80 \mathrm{~s}$ of the twentieth century $[29,30]$. Thus, in the work [29] it was found that lipopeptides synthesized by Bacillus subtilis B-3 were active against a wide range of phytopathogenic fungi. When tested for activity against Monilinia fructicola on peach fruits, these surfactants at a concentration of $1 \mathrm{mg} /$ $\mathrm{mL}$ caused complete suppression of brown rot. The minimum inhibitory concentrations (MIC) of fengycin synthesized by $B$. subtilis F-29-3 against phytopathogenic fungi were $(\mu \mathrm{g} / \mathrm{mL})$ : Pyricularia oryzae - 1.0; Conidiobolus coronatus - 3.16; Curvularia lunata - 3.16; Fusarium sp. - 10; Rhizomucor miehei - 10; Alternaria kikuchiana10; Rhizoctonia solani - 3.16 [30].

In the 90 s of the twentieth century, several other publications appeared on the antifungal activity of lipopeptides against phytopathogens synthesized by different strains of B. subtilis: NB22 [31], S499 [32], B-3 [33]. The turning point in these studies was the 2000s, which were marked by the appearance of a large number of articles on the action of surfactant lipopeptides on phytopathogenic microorganisms. Such information is very briefly given in a number of general reviews on lipopeptides of microbial origin published in 2008 [34], 2010 [35] and 2015 $[36,37]$.

In this review, we present data that were not included in the reviews [34-37], as well as information from recent years on the antimicrobial activity of lipopeptides against phytopathogens. 
In [38-51], the authors evaluated the antifungal activity of surfactant-containing supernatants. Such studies are promising from a practical point of view, as the use of the supernatant to control the number of phytopathogens makes it possible to exclude from the technological process a rather expensive stage of isolation and purification of the target product. The effect of supernatants on phytopathogenic fungi was analyzed by diffusion into agar, determining either the degree of inhibition of fungal growth (in percent), or the size of the zones of growth retardation (in $\mathrm{mm}$ ) (Table 1).

The data given in Table 1 show that under the effect of lipopeptide-containing supernatants, the degree of inhibition of various phytopathogenic fungi was in the range of $40-100 \%$, and the zones of growth retardation of fungi ranged from 1 to $29 \mathrm{~mm}$. However, it should be noted that most of these studies did not determine the content of lipopeptide surfactants in supernatants, so it is not possible to assess their effectiveness as antifungal agents, as well as to compare with other known microbial surfactants.

In [8-11, 44, 45, 47, 51-62] the antifungal activity of lipopeptides isolated from the supernatant and/or purified was investigated (Table 2). Some authors analyzed the effect on phytopathogenic fungi of total lipopeptides extracted with organic solvents from the supernatant of the culture broth $[8,10,44,45,47,53-58,60]$, some - individual lipopeptides isolated from a complex of surfactants

Table 1

Antimicrobial activity of lipopeptide-containing supernatants against phytopathogenic fungi

\begin{tabular}{|c|c|c|c|c|}
\hline \multirow[b]{2}{*}{$\begin{array}{l}\text { Lipopeptide producer } \\
\text { (amount of supernatant) }\end{array}$} & \multirow[b]{2}{*}{ Phytopathogenic fungi } & \multicolumn{2}{|c|}{ Antimicrobial activity } & \multirow[b]{2}{*}{$\begin{array}{l}\text { Litera- } \\
\text { ture }\end{array}$} \\
\hline & & $\begin{array}{c}\text { growth } \\
\text { inhibition, } \\
\%\end{array}$ & $\begin{array}{l}\text { growth } \\
\text { retardation } \\
\text { zone, } \mathrm{mm}\end{array}$ & \\
\hline \multirow[b]{2}{*}{$\begin{array}{l}\text { Bacillus subtilis M4 } \\
(50 \mu \mathrm{L} / \text { well })\end{array}$} & Pythium ultimum & & $1-4$ & \multirow[b]{2}{*}{ [39] } \\
\hline & $\begin{array}{c}\text { Fusarium oxysporum, } \\
\text { Rhizoctonia solani, } \\
\text { Rhizopus sp., Botrytis cinerea }\end{array}$ & & $5-9$ & \\
\hline \multirow{2}{*}{$\begin{array}{l}\text { Bacillus subtilis BBG100 } \\
(200 \mu \mathrm{L} / \text { well })\end{array}$} & $\begin{array}{c}\text { Fusarium oxysporum, } \\
\text { Pythium aphanidermatum }\end{array}$ & & $8-9$ & \multirow[t]{2}{*}[40]{} \\
\hline & Botrytis cinerea & & $\geq 10$ & \\
\hline \multirow{9}{*}{$\begin{array}{l}\text { Bacillus amyloliquefaciens } \\
\text { LBM } 5006 \\
(10 \mu \mathrm{L} / \text { disk })\end{array}$} & Aspergillus niger ATCC 16404 & & 10.5 & \multirow{9}{*}{ [44] } \\
\hline & Aspergillus phoencis & & 0 & \\
\hline & Aspergillus flavus & & 13.5 & \\
\hline & Apiosordaria sp. & & 13.5 & \\
\hline & Bipolaris sorokiniana & & 13.5 & \\
\hline & Cercosporina sojina & & 21 & \\
\hline & Diplodia $\mathrm{sp}$ & & 15.5 & \\
\hline & Fusarium oxysporum f. licopersici & & 0 & \\
\hline & Fusarium graminearum & & 0 & \\
\hline \multirow{2}{*}{$\begin{array}{l}\text { Bacillus subtilis SSE } 4 \\
\text { (in the presence of } 30 \% \text { of } \\
\text { supernatant in agar medium) }\end{array}$} & $\begin{array}{l}\text { Colletotrichum gloeosporioides } \\
\text { DOAC1690 }\end{array}$ & 100 & & \multirow[t]{2}{*}[43]{} \\
\hline & Sclerotium rolfsii DOAC 1521 & 92.6 & & \\
\hline \multirow{2}{*}{$\begin{array}{l}\text { Bacillus subtilis CPA-8 } \\
(100 \mu \mathrm{L} / \mathrm{well})\end{array}$} & Monilinia fructicola CPMC1 & 82.1 & & \multirow{2}{*}{ [45] } \\
\hline & Monilinia laxa CPML1 & 90 & & \\
\hline $\begin{array}{l}\text { Bacillus subtilis ABS-S14 } \\
(45 \mu \mathrm{L} / \text { cuvette) }\end{array}$ & Penicilium digitatum & 90.9 & & {$[47]$} \\
\hline \multirow{4}{*}{$\begin{array}{l}\text { Bacillus sp. PPM3 } \\
\text { (in the presence of } 2 \% \text { supernatant } \\
\text { in agar medium) }\end{array}$} & Mucor $\mathrm{sp}$. & 97.5 & & \multirow{4}{*}[48]{} \\
\hline & Aspergillus flavus & 82.7 & & \\
\hline & Fusarium graminearum & 57.1 & & \\
\hline & Alternaria $\mathrm{sp}$ & 41.5 & & \\
\hline \multirow{2}{*}{$\begin{array}{l}\text { Bacillus velezensis } \\
\text { NWUMFkBS10.5 (60 } \mu \mathrm{L} / \text { disk) }\end{array}$} & Fusarium graminearum & & 29 & \multirow{2}{*}[49]{} \\
\hline & Fusarium culmorum & & 24 & \\
\hline $\begin{array}{l}\text { Bacillus megaterium WL-3 } \\
(100 \mu \mathrm{L} / \text { disk })\end{array}$ & Phytophthora infestans & 73.3 & 9.5 & {$[51]$} \\
\hline
\end{tabular}


$[9,11,51,52,59,61,62]$. In the vast majority of studies indicators such as the degree of inhibition or growth retardation zones of fungi were used as a criterion for antifungal activity, and only in some studies the MIC was determined [10, 54-57, 60, 61]. Of particular note is the work [55], in which the authors analyzed the MIC of lipopeptides depending on the nature of the carbon source in the culture medium of the producer. It was found that strain AR2 synthesizes a mixture of homologues of iturin, fengycin and surfactin, and under conditions of growth on a medium with sucrose, glycerin, sorbitol and maltose, the same dominant fraction of the synthesized lipopeptide complex was $\mathrm{C} 15$ surfactin. However, the most active antifungal agents were lipopeptides synthesized on sucrose.

The data given in Table 2 show that lipopeptides of microbial origin have antimicrobial effect on phytopathogenic fungi in sufficiently high concentrations. Thus, the MIC of these products of microbial synthesis in relation to the genera Fusarium, Botrytis, Rhizoctonia, Monilinia, Aspergillus, Verticillium and others are 0.1 to 20 $\mathrm{mg} / \mathrm{mL}$ (see Table 2), while the minimum inhibitory concentrations for pathogenic fungi are lower $(4-32 \mu \mathrm{g} / \mathrm{mL})$ [36]. In addition, the antimicrobial activity of lipopeptide-containing supernatants (see Table 1) is not inferior to the effectiveness of antimicrobial activity of lipopeptides isolated from them (see Table 2), and therefore, to control the number of phytopathogenic fungi in crop production, it is more expedient to use surfactantcontaining supernatants.

\section{The effect of lipopeptides on phytopathogenic bacteria}

One of the first reports of antimicrobial activity of lipopeptides of microbial origin against phytopathogenic bacteria dates back to 1990 , when Phae et al. [31] reported the ability of the lipopeptide-containing $B$. subtilis NB22 supernatant and the five components of iturine isolated from it to inhibit the growth of Xanthomonas oryzae (the causative agent of bacterial burn of rice) and Pseudomonas lachrymans (the causative agent of angular spotting of cucumber leaves). Later studies by various authors conducted during 2004-2011 [63-65] also showed that the main component of lipopeptides responsible for antibacterial activity against phytopathogens is iturine. In addition to iturin, the antimicrobial effect on phytopathogenic bacteria was caused by the lipopeptides bacillomycin [65] and locillomycin
[66]. In 2020, Medeot et al. [69] reported that B. amyloliquefaciens MEP218 synthesizes fengycin with an antibacterial activity against Xanthomonas axonopodis pv. vesicatoria that distinguishes it from other fengycins, which are characterized mainly by antifungal action.

Generalized information about the antibacterial activity of lipopeptides $[8,31,43,63-70]$ is given in Table 3. The Table 3 does not include information on lipopeptides of B. velezensis 9D-6 [71], which inhibited the growth of phytopathogenic bacteria Ralstonia solanacearum, Xanthomonas campestris and Xanthomonas euvesicatoria, because in this work there are no indicators of antimicrobial activity of surfactants.

Note that in the literature there is much less information about the effect of surfactant lipopeptides on phytopathogenic bacteria compared to their antifungal activity. In addition, the minimum inhibitory concentrations of lipopeptides against phytopathogenic fungi are orders of magnitude higher (on average $0.04-8 \mathrm{mg} / \mathrm{mL}$, or $40^{-}$ $8000 \mu \mathrm{g} / \mathrm{mL}$ ) (see Table 2) than for phytopathogenic bacteria $(3-75 \mu \mathrm{g} / \mathrm{mL})$ (Table 3$)$. In our review [72] on the antimicrobial activity of surfactants, we focused on the fact that lipopeptides are characterized by high antibacterial activity also against pathogens of human infectious diseases (MIC $1-32 \mu \mathrm{g} / \mathrm{mL}$ ).

In our opinion, the different antimicrobial activity of lipopeptides against bacteria and fungi may be due to the following reasons. First, lipopeptides, like other secondary metabolites, are synthesized as a complex of similar compounds (most often iturin, surfactin and fengycin, which are characterized by different lengths of the acyl chain). Secondly, in the review [73] we noted that antifungal activity is inherent in lipopeptides with a longer (C16-C18) acyl chain, and lipopeptides with fewer carbon atoms $(\mathrm{C} 7-\mathrm{C} 14)$ in the fatty acid residue are characterized by antibacterial activity. Third, the antimicrobial activity of lipopeptides also depends on the composition and configuration of the acyl chain, the presence of certain substituents. Fourth, in recent years, information has begun to appear in the literature that the chemical composition of synthesized lipopeptides, and hence their biological activity, depends on the cultivation conditions of the producer [73]. Therefore, the antimicrobial activity of the lipopeptide complex is determined by the ratio in its composition of certain fractions with different lengths and configurations of the acyl chain. 


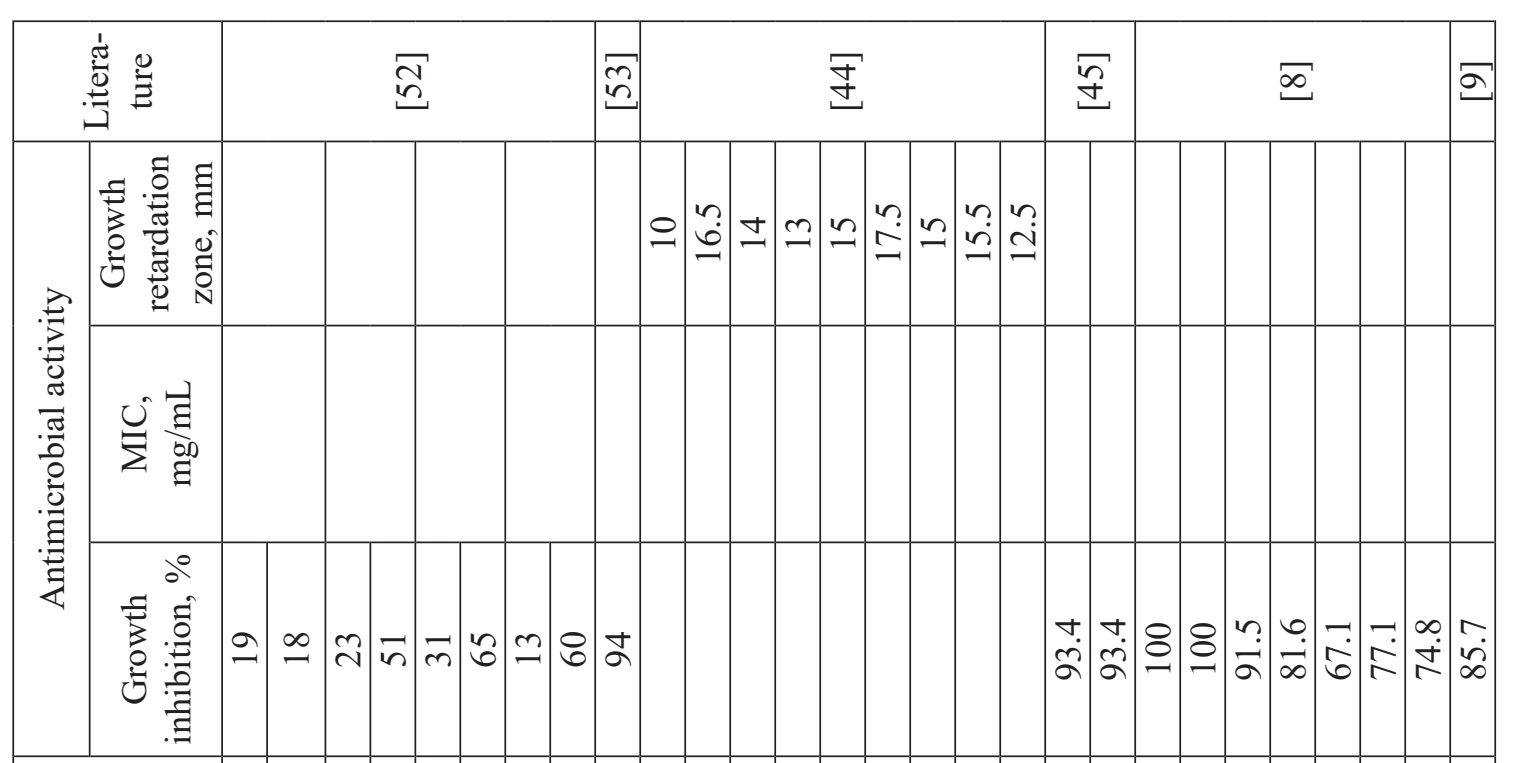

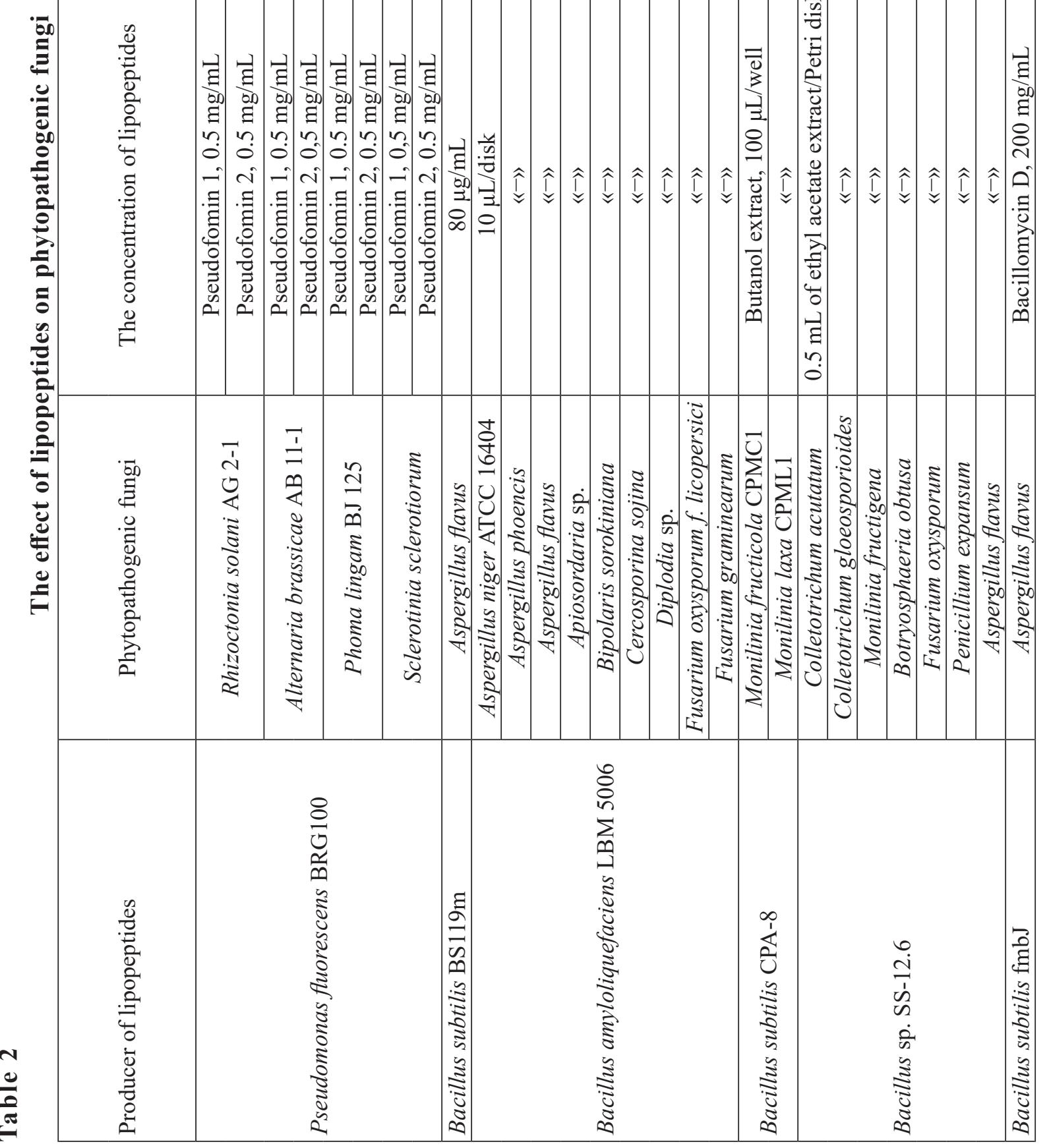




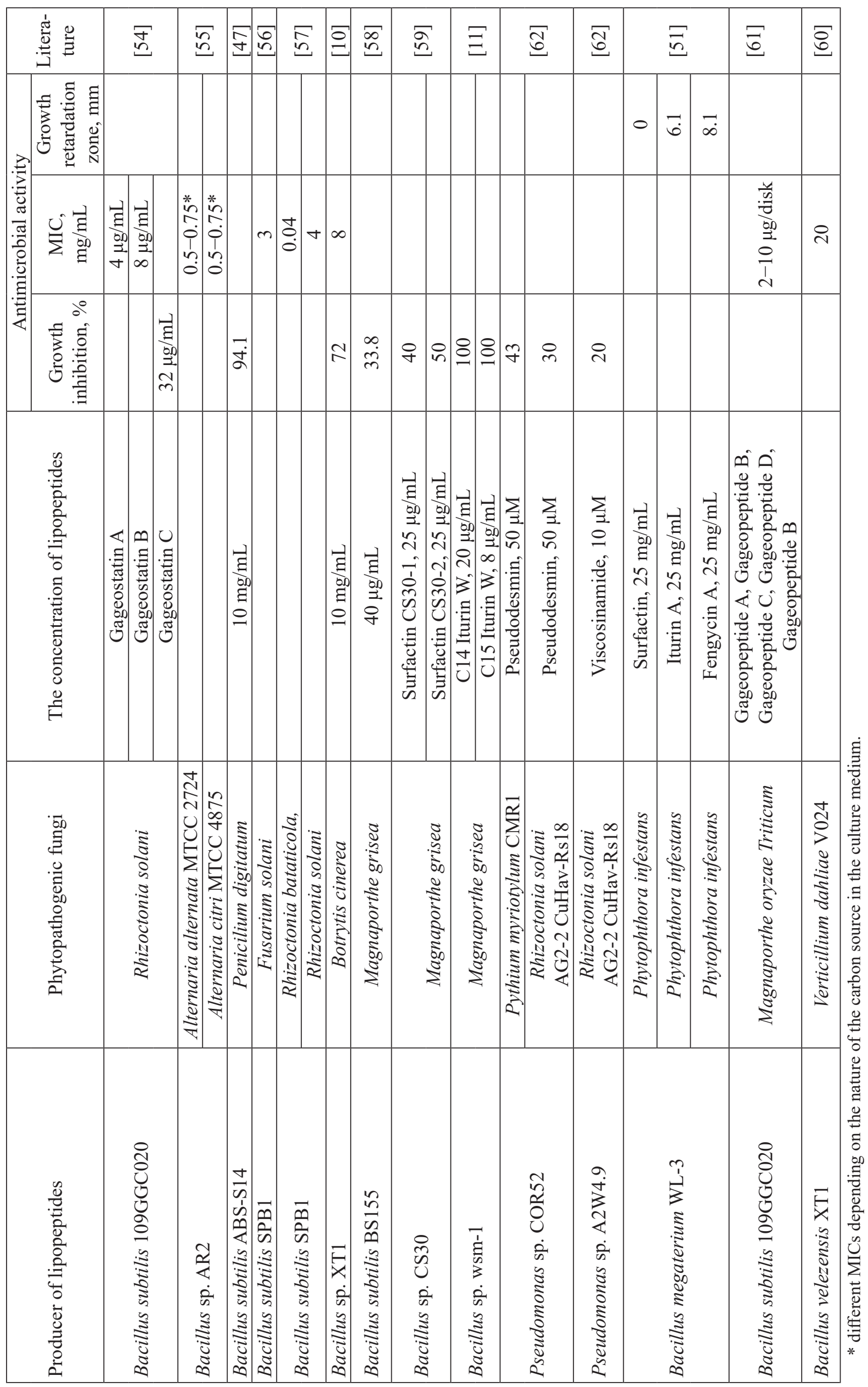




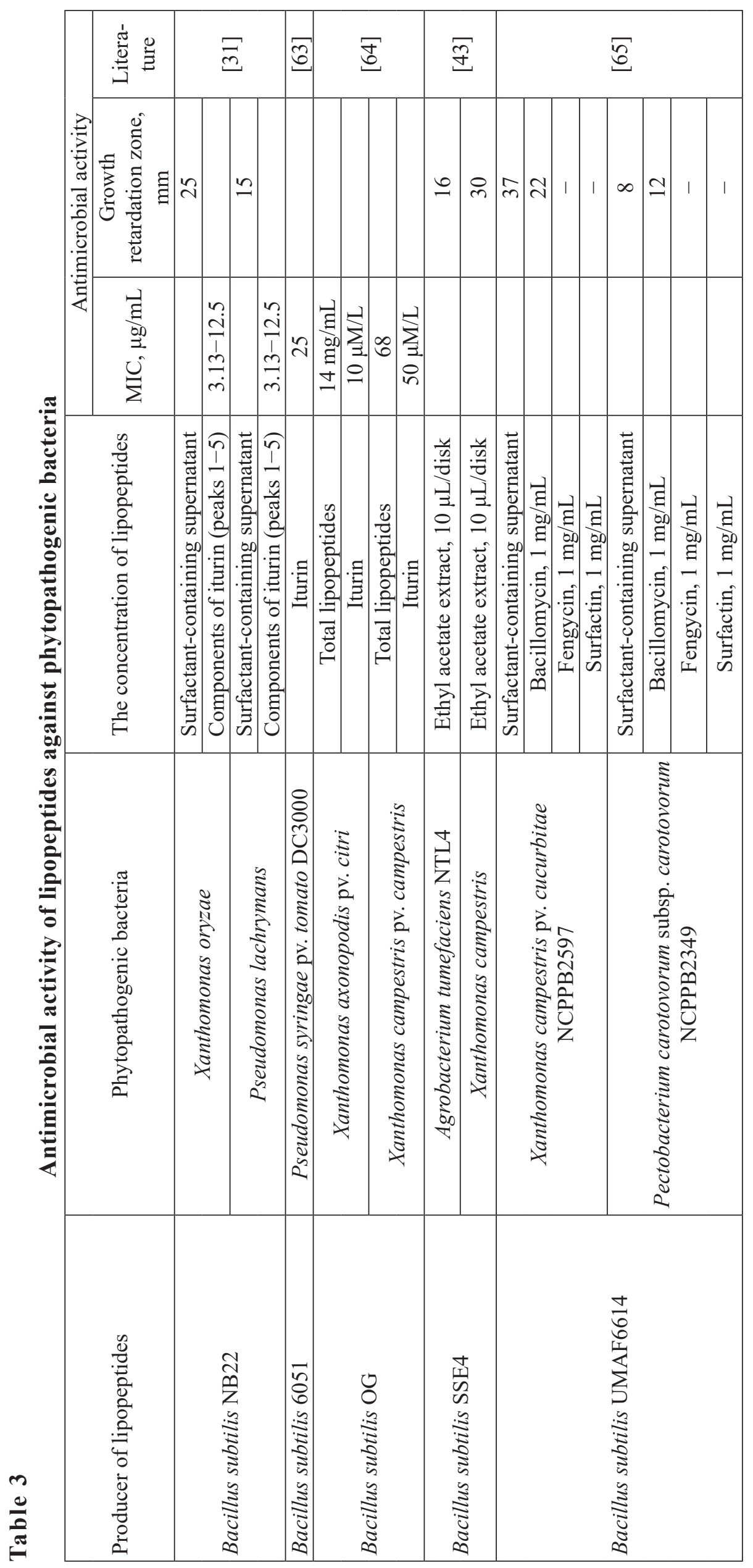




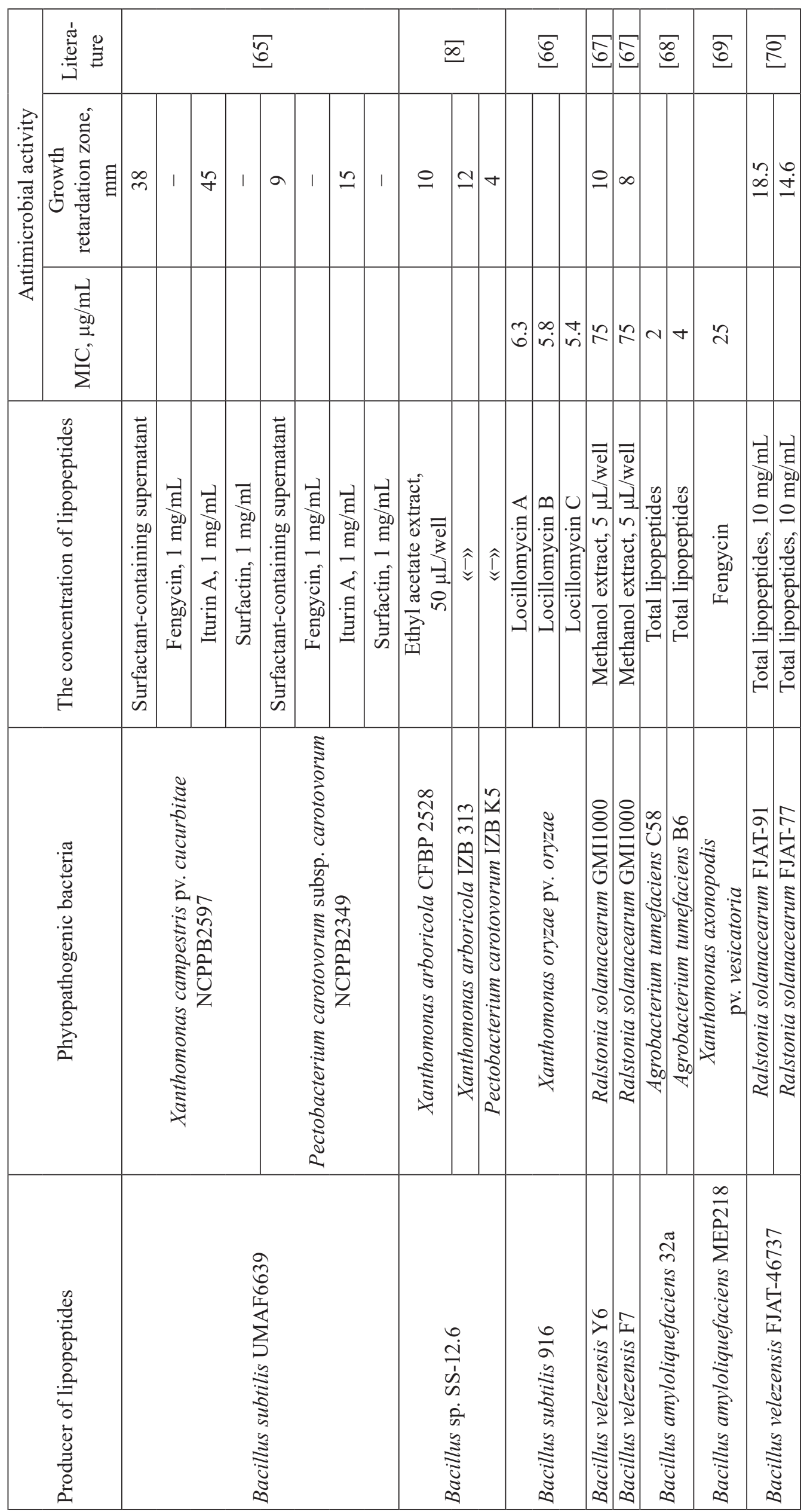




\section{Antimicrobial activity of rhamnolipids}

The first reports of the effect of microbial rhamnolipids on phytopathogenic microorganisms appeared in the 80-90s of the twentieth century [74, 75]. In [74] it was found that glycolipids (including rhamnolipids) of microbial origin inhibited the germination of conidia of the fungus Glomerella cingulata (the causative agent of anthracnose in various crops such as cereals and herbs, legumes, fruits, vegetables, perennial crops and trees). In 1997, Stanghellini and Miller [75] tested purified mono- and diramnolipids with a concentration of 5 to $30 \mu \mathrm{g} / \mathrm{mL}$ for zoosporicidal activity against three phytopathogens: Pythium aphanidermatum, Phytophthora capsici, Plasmopara lactucaeradicis. Lysosis of zoospores was observed under influence of rhamnolipids for less than $1 \mathrm{~min}$.

Generalized data published in articles 20012020 on the antimicrobial activity of rhamnolipids against phytopathogenic fungi are given in Table 4 . These data indicate no correlation between the concentration of rhamnolipids synthesized by different producers and the degree of inhibition of growth of phytopathogenic fungi. In our opinion, this can be explained as follows. First, it is known from the literature $[72,73]$ that the antimicrobial activity of surfactants of microbial origin depends on the type of test culture. Second, rhamnolipids are synthesized in the form of a complex of similar compounds, in particular, mono- and diramnolipids with different lengths of the acyl chain, and the antimicrobial activity of the target product depends on the ratio of these chains [73]. The data presented in the works $[24,88,90]$ support the second assumption. Thus, Rodrigues et al. [88] found that rhamnolipid-containing supernatant of $P$. aeruginosa \#112 and a solution of extracted from it total rhamnolipids (surfactant concentration $3 \mathrm{~g} / \mathrm{L}$ ) caused inhibition of growth of Aspergillus niger MUM 92.13 by 75.5 and $28.6 \%$, respectively, and isolated from the mixture mono- and diramnolipids with a concentration of $1.5 \mathrm{~g} / \mathrm{L}$ - by 46.2 and $40 \%$, respectively. Monnier et al. [90] showed that the inhibition of growth of Leptosphaeria maculans under the effect of $0.5 \mathrm{~g} / \mathrm{L}$ of semipurified commercial rhamnolipids was $60 \%$ (if the preparation contained 66 and $34 \%$ of mono- and rhamnolipids) and $73 \%$ in the presence of 41 and $59 \%$ mono- and diramnolipids, respectively.

In [24], it was found that the MIC of rhamnolipids (ready-made preparations synthesized by Pseudomonas aeruginosa were used) for Zymoseptoria tritici were higher than $1500 \mu \mathrm{M}$. At the same time, some chemically synthesized derivatives of rhamnolipids containing 12 carbon atoms in the acyl chain were characterized by higher antimicrobial activity $(133-450 \mu \mathrm{M})$ relative to this test culture.

The data given in Table 4 show that rhamnolipids with antifungal properties can be obtained from cheap and available in large quantities industrial waste [76-78, 83, 88]. In the review [72], we noted that in the literature there is little information about the antimicrobial activity of surfactants synthesized on such substrates.

In contrast to the data on the antifungal activity of rhamnolipids against phytopathogens, information on the effect of these surfactants on phytopathogenic bacteria is quite limited. Thus, in 2000 [91] it was found that the MIC of rhamnolipids synthesized by $P$. aeruginosa B5 against phytopathogens Erwinia carotovora pv. carotovora, Ralstonia solanacearum and Xanthomonas campestris pv. vesicatoria, which affect most of the agricultural plants, were $>50 \mu \mathrm{g} / \mathrm{mL}$. In 2012, Sanchez et al. [12] showed that the cultivation of Pseudomonas syringae pv. tomato DC3000 and Pseudomonas syringae pv. tomato AvrRPM1 in the presence of 0.2 and $1 \mathrm{mg} / \mathrm{mL}$ rhamnolipids did not inhibit the growth of phytopathogenic bacteria. In 2016, Leite et al. [92] found that under the action of $15 \mu \mathrm{L}$ of supernatant (rhamnolipid concentration $0.57 \mathrm{~g} / \mathrm{L}$ ) obtained after culturing $P$. aeruginosa P1R16 on olive oil, the growth retardation zone of Ralstonia solanacearum 1226 was $22 \mathrm{~mm}$. Finally, in 2020 [25] it was shown that the MIC of diramnolipid for Xanthomonas campestris, synthesized by $P$. aeruginosa RTE4 on glucose ( $2 \%$ ) was $5 \mathrm{mg} / \mathrm{mL}$.

However, there is enough information in the literature about the antimicrobial activity of rhamnolipids against pathogenic for humans bacteria [23, 28, 72, 93]. Note that the MIC of rhamnolipids against human pathogens are orders of magnitude lower $(50-500 \mu \mathrm{g} / \mathrm{mL})$ than for phytopathogenic bacteria (above $5000 \mu \mathrm{g} /$ $\mathrm{mL})$. Nevertheless, the conclusion about the antimicrobial activity of rhamnolipids against phytopathogens is made only on the basis of several works available in the literature.

\section{Effect of sophorolipids on phytopathogenic microorganisms}

The first reports of antimicrobial activity of the surface-active sophorolipids on phytopathogenic fungi appeared in the early 2000s, when Kim et al. [94] established the ability of these surfactants at a concentration of $300 \mathrm{mg} / \mathrm{L}$ to inhibit the growth 


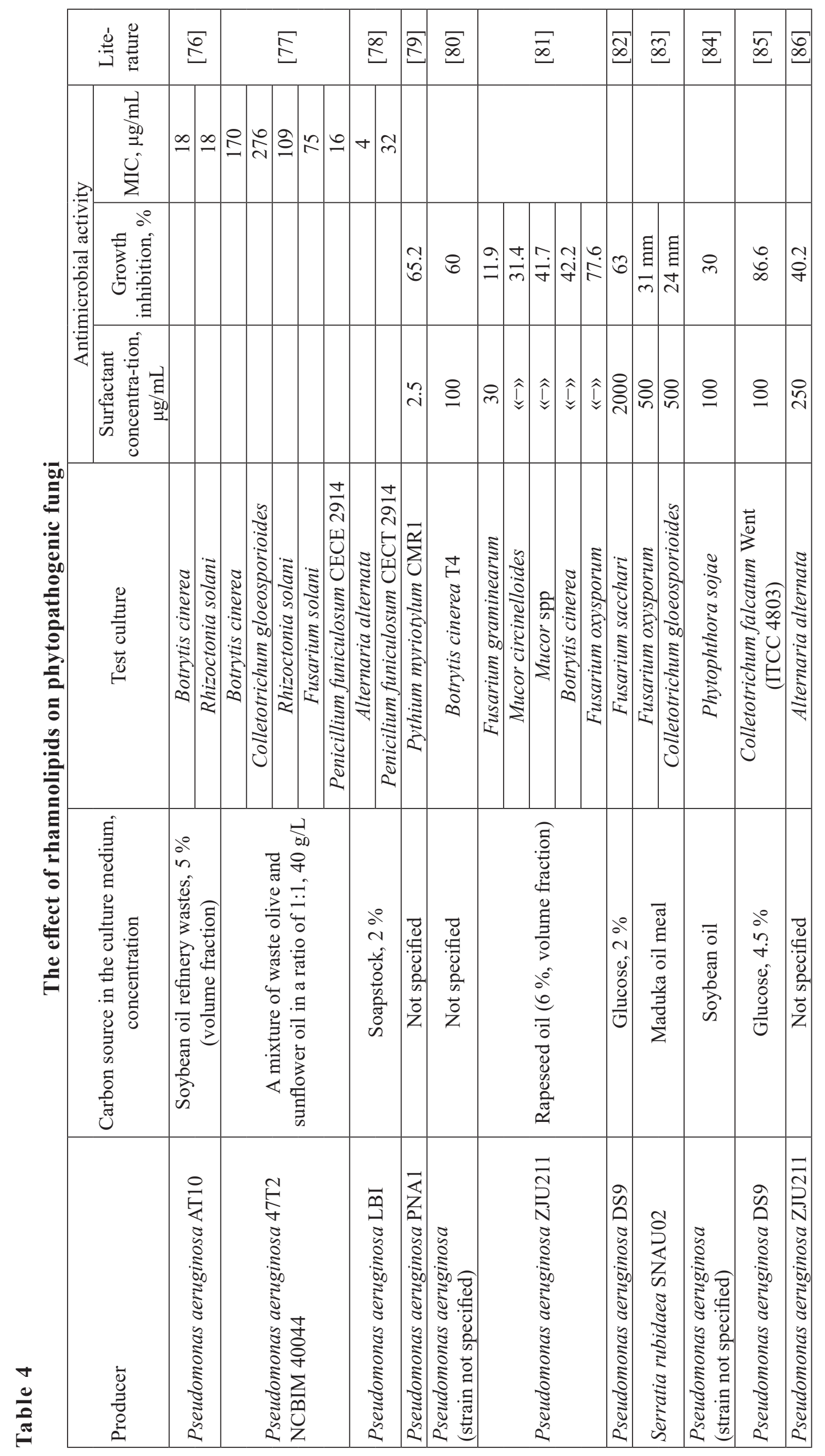




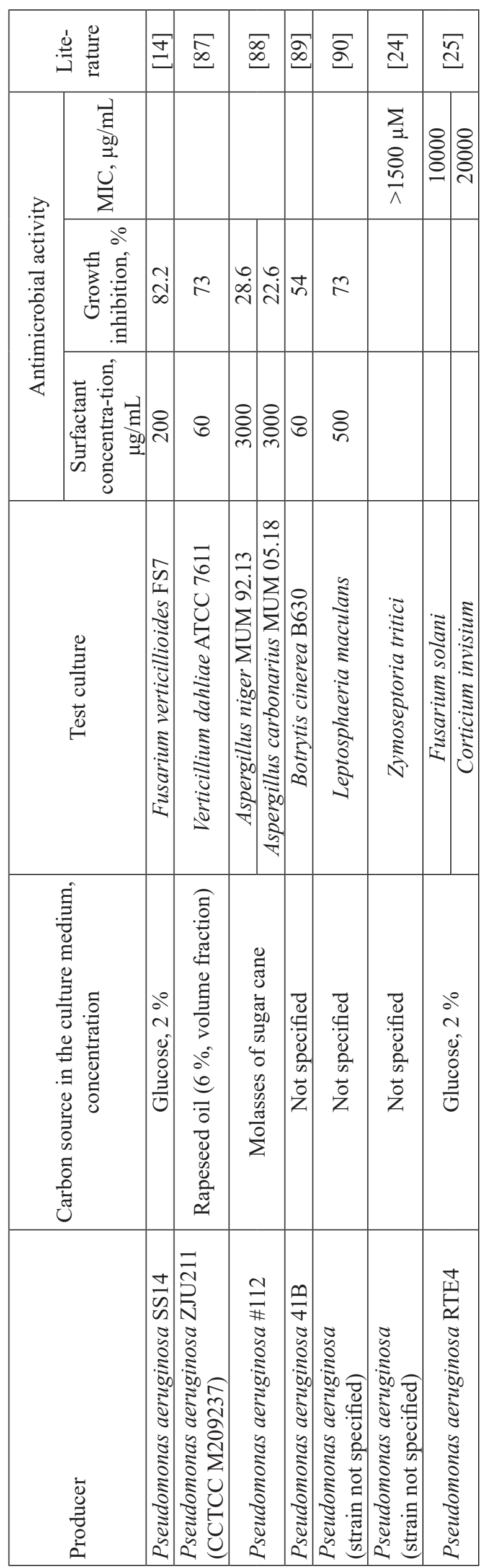


of B. cinerea KCTC 6973 by $57 \%$. To obtain sophorolipids, the producer Candida bombicola ATCC 22214 was grown in glucose medium $(100 \mathrm{~g} / \mathrm{L})$.

Note that at present there is little information in the literature about the effect of sophorolipids on phytopathogenic microorganisms [26, 27, 95-97]. Moreover, all these works are exclusively about the antifungal activity of sophorolipids, and only one article [97] reported their ability to inhibit the growth of phytopathogenic bacteria.

Yoo et al. [95] found that sophorolipids synthesized by $C$. bombicola ATCC 22214 in glucose medium $(100 \mathrm{~g} / \mathrm{L})$ at a concentration of $100 \mathrm{mg} / \mathrm{L}$ inhibited the growth of Pythium ultimum KACC 40705 by $90 \%$, and at a concentration of 500 $\mathrm{mg} / \mathrm{L}$ inhibited by $80 \%$ the growth of another member of the genus Pythium (P. aphanidermatum KACC 40156), as well as members of the genus Phytophthora ( $P$. capsici, P. nicotianae KACC 40906, P. infestans KACC 40718).

The efficacy of sophorolipids synthesized by Wickerhamiella domercqiae Y2A in medium with glucose $(80 \mathrm{~g} / \mathrm{L})$ and rapeseed oil $(80 \mathrm{~g} / \mathrm{L})$ against nine strains of phytopathogenic fungi of the genera Penicillium, Aspergillus, Botrytis and Mucor, which cause mold on apples, pears, oranges, peaches and dates. Thus, at a concentration of sophorolipids $1 \mathrm{~g} / \mathrm{L}$ inhibition of growth of these fungi was (\%): 60-75, under action of $3 \mathrm{~g} / \mathrm{L}-82-91$, and $10 \mathrm{~g} / \mathrm{L}-96-100$.

Schofield et al. [97] reported that sophorolipid derivatives (with different degrees of lactonization and acetylation, as well as different acyl chain lengths) and combinations of sophorolipid derivatives showed antifungal activity against 18 fungal pathogens (Alternaria tomatophilia, Alternaria solani, Alternaria alternata, Aspergi- llus niger, Aureobasidium pullulans, B. cinerea, Chaetomium globosum, Fusarium asiaticum, Fusarium austroamericana, Fusarium cerealis, Fusarium graminearum, Fusarium oxysporum, Penicillium chrysogenum, Penicillium digitatum, Penicillium funiculosum, $P$. infestans, $P$. capsici, Ustilago maydis) and seven bacterial phytopathogens (Acidovorax carotovorum, Erwinia amylovora, Pseudomonas cichorii, Pseudomonas syringae, Pectobacterium carotovorum, Ralstonia solanacearum and Xanthomonas campestris). MIC ranged from 2.5 to $10 \mathrm{mg} / \mathrm{mL}$ for individual sophorolipid derivatives and from 0.009 to $10 \mathrm{mg} /$ $\mathrm{mL}$ for combinations of these surfactants.

In 2017 [26], antifungal activity of sophorolipids synthesized by Rhodotorula babjevae YS3 on glucose medium $(10 \mathrm{~g} / \mathrm{L})$ was reported. The MIC for Colletotrichum gloeosporioides ITCC 6434 was $62 \mu \mathrm{g} / \mathrm{mL}$, Fusarium verticilliodes MTCC 10556, Fusarium oxysporum $f$. sp. pisi ITCC $4814-125 \mu \mathrm{g} / \mathrm{mL}$, while for Corynespora cassiicola ITCC 6748 MIC was significantly higher (>2000 $\mu \mathrm{g} / \mathrm{mL}$ ).

Chen et al. [27] found that sophorolipids synthesized by Wickerhamiella domercqiae $\mathrm{Y}_{2 \mathrm{~A}}$ in glucose medium ( $8 \%$ ) have antifungal activity against phytopathogenic fungi (Table 5). The data given in Table 5 indicate that the maximum level of growth inhibition of test cultures (68-98\%) was achieved at the highest of the studied surfactant concentrations $(10 \mathrm{mg} / \mathrm{mL})$.

It should be noted that, in contrast to surfactant lipopeptides and rhamnolipids (see Tables 2-4), the effective concentration of most sophorolipids, which provides the highest antimicrobial activity against phytopathogens, is higher and reaches several $\mathrm{mg} / \mathrm{mL}$.

\section{Table 5}

The effect of Wickerhamiella domercqiae $\mathrm{Y}_{2 \mathrm{~A}}$ sophorolipids on phytopathogenic fungi [27]

\begin{tabular}{|l|c|c|c|}
\hline \multirow{2}{*}{ Test culture } & \multicolumn{3}{|c|}{$\begin{array}{c}\text { Inhibition of growth (\%) at the concentration of sophorolipids } \\
(\mathrm{mg} / \mathrm{mL})\end{array}$} \\
\cline { 2 - 4 } & 0.5 & 3 & 10 \\
\hline Pyricularia oryzae AX1105 & 55.88 & 82.15 & 89.50 \\
\hline Rhizoctorzia solani & 75.46 & 84.25 & 87.05 \\
\hline Pythium ultimum ACCC 36075 & 97.2 & 98.2 & 98.12 \\
\hline Fusarium oxysporum ACCC 36468 & 59.09 & 66.16 & 69.70 \\
\hline Fusarium concentricum & 61.14 & 67.88 & 68.16 \\
\hline Fusarium sp. ACCC 36194 & 58.11 & 68.67 & 71.27 \\
\hline Phytophthora infestans & 69.51 & 73.98 & 74.98 \\
\hline Gaeumannomyces graminis var. Tritici & 50.83 & 68.01 & 73.06 \\
\hline
\end{tabular}


$* * *$

Thus, the analysis of literature data showed that surfactants of microbial origin (lipopeptides, rhamnolipids and sophorolipids) cause antimicrobial action on phytopathogenic fungi and bacteria, and the vast majority of studies relate to the antifungal effect of these surfactants. However, the problem of today is the fight against bacteriosis of crops, which we have focused on in our previous works [7, 98].

Despite a sufficient number of studies on the effect of rhamnolipids on phytopathogenic fungi, published during 2001-2020 [14, 24, 25, 76-90], such studies are still less than those with lipopeptides. In our opinion, this is primarily due to the fact that in recent years lipopeptides have been actively studied as useful for plants products of metabolism of rhizospheric and endophytic bacteria of the genus Bacillus [7, 19-22, 50, 67, 71].

Nevertheless, rhamnolipids have a significant advantage as antimicrobial agents over lipopeptides because the MIC values of rhamnolipids relative to phytopathogenic fungi $(4-276 \mu \mathrm{g} / \mathrm{mL})$ are lower than lipopeptides $(40-8000 \mu \mathrm{g} / \mathrm{mL})$. In addition, rhamnolipids with antifungal properties can be obtained from cheap and available in large quantities industrial waste [76-78, 83, 88]. Note that the level of microbial synthesis of rhamnolipids (up to $40 \mathrm{~g} / \mathrm{L}$, [99]) is significantly higher than lipopeptides (usually not more than $1-3 \mathrm{~g} / \mathrm{L},[100]$ ).

Much less (compared to rhamnolipids and lipopeptides) in the literature there are reports of the effect of sophorolipids on phytopathogenic microorganisms, in particular, only on their antifungal activity. One of the reasons for the low interest of researchers in sophorolipids as antimicrobial agents against phytopathogens is the rather high minimum inhibitory concentrations of these surfactants (up to $10,000 \mu \mathrm{g} / \mathrm{mL}$ ).

\section{ВПЛИВ ПОВЕРХНЕВО-АКТИВНИХ РЕЧОВИН МІКРОБНОГО ПОХОД- ЖЕННЯ НА ФІТОПАТОГЕННІ МІКРООРГАНІЗМИ}

\author{
Т.П. Пирог',2, Д.В. П'ятецька', \\ Г.А. Ярова ${ }^{1}$, Г.О. Іутинська ${ }^{2}$
}

${ }^{1}$ Національний університет харчових технологій, вул. Володимирська, 68, Київ, 01601, Україна

${ }^{2}$ Інститут мікробіології і вірусології ім. Д.К. Заболотного НАН Украӥни, вул. Академіка Заболотного, 154, Київ, 03143, Україна

\section{Резюме}

Біодеградабельні нетоксичні поверхнево-активні речовини мікробного походження $€$ препаратами мультифункціонального призначення, які завдяки антимікробній активності $є$ перспективними для використання у рослинництві для боротьби 3 фітопатогенними мікроорганізмами. Дослідження, присвячені перспективам використання мікробних ПАР для контролю чисельності фітопатогенних мікроорганізмів, проводяться у трьох напрямах: лабораторні дослідження антимікробної активності поверхнево-активних речовин in vitro, визначення впливу поверхзнево-активних речовин на фітопатогени у вегетаційних дослідах у процесі вирощування рослин в лабораторії чи теплиці, післяврожайна обробка фруктів та овочів розчинами мікробних ПАР з метою подовження терміну їх зберігання. В огляді наведено дані літератури про антимікробну щодо фітопатогенних бактерій і грибів активність поверхнево-активних речовин in vitro. Антимікробну активність поверхнево-активних речовин оцінюють за трьома основними показниками: мінімальна інгібуюча концентрація, зони затримки росту тест-культур на агаризованих середовищах і інгібування росту тест-культур на агаризованих або в рідких середовищах. Переважна більшість наявних публікацій стосуються антифунгальної активності поверхнево-активних ліпопептидів та рамноліпідів, у той час як дані про дію цих мікробних ПАР на фітопатогенні бактерії (представників родів Ralstonia, Xanthomonas, Pseudomonas, Agrobacterium, Pectobacterium) e небагаточисельними. Дослідники визначали антимікробну активність або сумарних ліпопептидів, екстрагованих із супернатанту культуральної рідини органічними розчинниками, або індивідуальних ліпопептидів (ітурин, сурфактин, фенгіцин та ін.), виділених з комплексу поверхнево-актив- 
них речовин, або супернатанту культуральної рідини. Ліпопептиди, синтезовані представниками роду Bacillus проявляють антимікробну дію на фітопатогенні гриби родів Alternaria, Verticillium, Aspergillus, Aureobasidium, Botrytis, Rhizoctonia, Fusarium, Penicillium, Phytophora, Sclerotinia, Curvularia, Colletotrichum та ін. у достатньо високих концентраціях. Так, мінімальні інгібуючі концентрації ліпопептидів щодо фітопатогенних грибів $\epsilon$ на порядки вищими (в середньому 0,04-8 мг/мл, або 40-8000 мкг/мл), ніж щодо фітопатогенних бактерій (3-75 мкг/мл). Разом з тим антифунгальна активність ліпопептидвмісних супернатантів не поступається за ефективністю активності виділених з них ліпопептидів, а отже, для контролю чисельності фітопатогенних грибів у рослинництві доцільнішим є використання саме ліпопептид-вмісних супернатантів. Рамноліпіди, синтезовані бактеріями роду Pseudomonas, $\epsilon$ ефективнішими антимікробними агентами порівняно з ліпопептидами: мінімальні інгібуючі концентрації рамноліпідів щодо фітопатогенних грибів становлять 4-276 мкг/мл, що на порядок

1. Jimoh AA, Lin J. Biosurfactant: A new frontier for greener technology and environmental sustainability. Ecotoxicol Environ Saf. 2019; 184:109607. doi: 10.1016/j.ecoenv.2019.109607.

2. Adu SA, Naughton PJ, Marchant R, Banat IM. Microbial biosurfactants in cosmetic and personal skincare pharmaceutical formulations. Pharmaceutics. 2020;12(11):1099. doi: 10.3390/ pharmaceutics 12111099 .

3. Ribeiro BG, Guerra JMC, Sarubbo LA. Biosurfactants: production and application prospects in the food industry. Biotechnol Prog. 2020; 36(5):e3030. doi: 10.1002/btpr.3030.

4. Adetunji AI, Olaniran AO. Production and potential biotechnological applications of microbial surfactants: An overview. Saudi J Biol Sci. 2021; 28(1):669-79. doi: 10.1016/j.sjbs.2020.10. 058 .

5. Mnif I, Ghribi D. Glycolipid biosurfactants: main properties and potential applications in agriculture and food industry. J Sci Food Agric. 2016; 96(13):4310-20. doi: 10.1002/jsfa.7759.

6. Crouzet J, Arguelles-Arias A, Dhondt-Cordelier S, Cordelier S, Pršić J, Hoff G, et al. Biosurfactants in plant protection against diseases: нижче, ніж ліпопептидів. На відміну від даних про антифунгальну щодо фітопатогенів активність рамноліпідів у літературі є всього кілька повідомлень про дію цих поверхнево-активних речовин на фітопатогенні бактерії, при цьому мінімальні інгібуючі концентрації є достатньо високими (до 5000 мкг/мл). Перевагою рамноліпідів як антимікробних агентів порівняно з ліпопептидами $є$ високий рівень синтезу на дешевих і наявних у великих кількостях промислових відходах. На даний час у літературі $є$ небагато інформації про дію поверхнево-активних софороліпідів мікробного походження на фітопатогенні гриби, причому у всіх цих роботах мова йде переважно про антифунгальну активність софороліпідів. Зазначимо, що на відміну від поверхнево-активних ліпопептидів і рамноліпідів ефективна концентрація більшості софороліпідів, що забезпечує найвищу антимікробну щодо фітопатогенів активність, є вищою і досягає 10000 мкг/мл.

Ключові слова: антимікробна активність, фітопатогенні гриби, фітопатогенні бактерії, ліпопептиди, рамноліпіди, софороліпіди.

rhamnolipids and lipopeptides case study. Front Bioeng Biotechnol. 2020; 8:1014. doi: 10.3389/ fbioe.2020.01014.

7. Pirog TP, Paliichuk OI, Iutynska GO, Shevchuk TA. [Prospects of using microbial surfactants in plant growing]. Mikrobiol Z. 2018; 80(3):115-35. Ukrainian. doi: https://doi. org/10.15407/microbiolj80.03.115.

8. Dimkić I, Živković S, Berić T, Ivanović Ž, Gavrilović V, Stanković S, et al. Characterization and evaluation of two Bacillus strains, SS-12.6 and SS-13.1, as potential agents for the control of phytopathogenic bacteria and fungi. Biol Control. 2013; 65(3):312-21. doi:10.1016/j.biocontrol.2013.03.012.

9. Gong Q, Zhang C, Lu F, Zhao H, Bie X, Lu Z. Identification of bacillomycin $\mathrm{D}$ from Bacillus subtilis fmbJ and its inhibition effects against $A s$ pergillus flavus. Food Control. 2014; 36(1):8-14. doi:10.1016/j.foodcont.2013.07.034.

10. Toral L, Rodríguez M, Béjar V, Sampedro I. Antifungal activity of lipopeptides from Bacillus XT1 CECT 8661 against Botrytis cinerea. Front Microbiol. 2018; 9:1315. doi: 10.3389/ fmicb.2018.01315. 
11. Zhou S, Liu G, Zheng R, Sun C, Wu S. Structural and functional insights into iturin $\mathrm{W}$, a novel lipopeptide produced by the deep-sea bacterium Bacillus sp. strain wsm-1. Appl Environ Microbiol. 2020; 86(21):e01597-20. doi: 10.1128/ AEM.01597-20.

12. Sanchez L, Courteaux B, Hubert J, Kauffmann S, Renault JH, Clément C, et al. Rhamnolipids elicit defense responses and induce disease resistance against biotrophic, hemibiotrophic, and necrotrophic pathogens that require different signaling pathways in Arabidopsis and highlight a central role for salicylic acid. Plant Physiol. 2012; 160(3):1630-41. doi: 10.1104/pp.112.201913.

13. Guo Q, Dong W, Li S, Lu X, Wang P, Zhang X, et al. Fengycin produced by Bacillus subtilis NCD-2 plays a major role in biocontrol of cotton seedling damping-off disease. Microbiol Res. 2014; 169(7-8):533-40. doi: 10.1016/j.micres.2013.12.001.

14. Borah SN, Goswami D, Sarma HK, Cameotra SS, Deka S. Rhamnolipid biosurfactant against Fusarium verticillioides to control stalk and ear rot disease of maize. Front Microbiol. 2016; 7:1505. doi: 10.3389/fmicb.2016.01505.

15. Yang L, Han X, Zhang F, Goodwin PH, Yang Y, Li J, et al. Screening Bacillus species as biological control agents of Gaeumannomyces graminis var. Tritici on wheat. Biological Control. 2018; 118:1-9. doi:10.1016/j.biocontrol.2017.11.004

16. Adetunji CO, Adejumo IO, Afolabi IS, Adetunji JB, Ajisejiri ES. Prolonging the shelf life of "Agege Sweet" orange with chitosan-rhamnolipid coating. Horticulture, Environment, and Biotechnology. 2018; https://doi.org/10.1007/ s13580-018-0083-2.

17. Sharma V, Garg M, Devismita T, Thakur P, Henkel M, Kumar G. Preservation of microbial spoilage of food by biosurfactant-based coating. Asian J Pharm Clin Res. 2018; 11(2):98-101.

18. Pirog T, Beregova K, Geichenko B, Stabnikov V. Application of surface-active substances produced by Nocardia vaccinii IMB B-7405 for the treatment of vegetables. Ukr Food J. 2019; 8(1):99-109. doi:10.24263/2304-974X2019-8-1-11.
19. Kaspar F, Neubauer P, Gimpel M. Bioactive secondary metabolites from Bacillus subtilis: a comprehensive review. J Nat Prod. 2019; 82(7):2038-53. doi: 10.1021/acs.jnatprod. 9b00110.

20. Legein M, Smets W, Vandenheuvel D, Eilers T, Muyshondt B, Prinsen E, Samson R, Lebeer S. Modes of action of microbial biocontrol in the phyllosphere. Front Microbiol. 2020; 11:1619. doi: 10.3389/fmicb.2020.01619.

21. Malviya D, Sahu PK, Singh UB, Paul S, Gupta A, Gupta AR, et al. Lesson from ecotoxicity: revisiting the microbial lipopeptides for the management of emerging diseases for crop protection. Int J Environ Res Public Health. 2020; 17(4):1434. doi: 10.3390/ijerph17041434.

22. Penha RO, Vandenberghe LPS, Faulds C, Soccol VT, Soccol CR. Bacillus lipopeptides as powerful pest control agents for a more sustainable and healthy agriculture: recent studies and innovations. Planta. 2020; 251(3):70. doi: 10.1007/ s00425-020-03357-7.

23. Chen J, Wu Q, Hua Y, Chen J, Zhang H, Wang H. Potential applications of biosurfactant rhamnolipids in agriculture and biomedicine. Appl Microbiol Biotechnol. 2017;101 (23-24):8309-8319. doi: 10.1007/s00253-0178554-4.

24. Platel R, Chaveriat L, Le Guenic S, Pipeleers R, Magnin-Robert M, Randoux B, et al. Importance of the $\mathrm{C} 12$ carbon chain in the biological activity of rhamnolipids conferring protection in wheat against Zymoseptoria tritici. Molecules. 2020; 26(1):40. doi: 10.3390/molecules26010040.

25. Chopra A, Bobate S, Rahi P, Banpurkar A, Mazumder PB, Satpute S. Pseudomonas aeruginosa RTE4: A tea rhizobacterium with potential for plant growth promotion and biosurfactant production. Front Bioeng Biotechnol. 2020; 8:861. doi: 10.3389/fbioe.2020.00861

26. Sen S, Borah SN, Bora A, Deka S. Production, characterization, and antifungal activity of a biosurfactant produced by Rhodotorula babjevae YS3. Microb Cell Fact. 2017;16(1):95. doi: 10.1186/s12934-017-0711-z. 
27. Chen J, Liu X, Fu S, An Z, Feng Y, Wang R, et al. Effects of sophorolipids on fungal and oomycete pathogens in relation to $\mathrm{pH}$ solubility. J Appl Microbiol. 2020; 128(6):1754-63. doi: 10.1111/jam.14594.

28. Shu Q, Lou H, Wei T, Liu X, Chen Q. Contributions of glycolipid biosurfactants and glycolipid-modified materials to antimicrobial strategy: a review. Pharmaceutics. 2021;13(2):227. doi: 10.3390/pharmaceutics13020227.

29. McKeen CD, Reilly CC, Pusey PL. Production and partial characterization of antifungal substances antagonistic to Monilinia fructicola from Bacillus subtilis. Phytopathology. 1986; 76:1369.

30. Vanittanakom N, Loeffer W, Koch U, Jung G. Fengycin - a novel antifungal lipopeptide antibiotic produced by Bacillus subtilis F-29-3. J Antibiot (Tokyo). 1986; 39:888-901.

31. Phae CG, Shoda M, Kubota H. Suppressive effect of Bacillus subtilis and it's products on phytopathogenic microorganisms. J Ferment Bioeng. 1990; 69(1):1-7. doi:10.1016/0922338x(90)90155-p.

32. Razafindralambo H, Paquot M, Hbid C, Jacques P, Destain J, Thonart P. Purification of antifungal lipopeptides by reversed-phase high-performance liquid chromatography. J Chromatogr. 1993; 639(1):81-5. doi: 10.1016/ 0021-9673(93)83091-6.

33. Klich MA, Arthur KS, Lax AR, Bland JM. Iturin A: a potential new fungicide for stored grains. Mycopathologia. 1994; 127(2):123-7. doi: 10. 1007/BF01103068.

34. Ongena M, Jacques P. Bacillus lipopeptides: versatile weapons for plant disease biocontrol. Trends Microbiol. 2008; 16(3):115-25. doi: 10.1016/j.tim.2007.12.009.

35. Raaijmakers JM, De Bruijn I, Nybroe O, Ongena M. Natural functions of lipopeptides from Bacillus and Pseudomonas: more than surfactants and antibiotics. FEMS Microbiol Rev. 2010; 34(6):1037-62. doi: 10.1111/j.15746976.2010.00221.x.

36. Inès $\mathrm{M}$, Dhouha $\mathrm{G}$. Lipopeptide surfactants: production, recovery and pore forming capacity. Peptides. 2015; 71:100-12. doi: 10.1016/j.pep- tides.2015.07.006.

37. Mnif I, Ghribi D. Review lipopeptides biosurfactants: Mean classes and new insights for industrial, biomedical, and environmental applications. Biopolymers. 2015;104(3):129-47. doi: 10.1002/ bip. 22630.

38. Touré Y, Ongena M, Jacques P, Guiro A, Thonart P. Role of lipopeptides produced by Bacillus subtilis GA1 in the reduction of grey mould disease caused by Botrytis cinerea on apple. J Appl Microbiol. 2004; 96(5):1151-60. doi: 10.1111/j.1365-2672.2004.02252.x.

39. Ongena M, Jacques P, Touré Y, Destain J, Jabrane A, Thonart P. Involvement of fengycin-type lipopeptides in the multifaceted biocontrol potential of Bacillus subtilis. Appl Microbiol Biotechnol. 2005; 69(1):29-38. doi: 10.1007/ s00253-005-1940-3.

40. Leclère V, Béchet M, Adam A, Guez JS, Wathelet B, Ongena M, et al. Mycosubtilin overproduction by Bacillus subtilis BBG100 enhances the organism's antagonistic and biocontrol activities. Appl Environ Microbiol. 2005; 71(8):4577-84. doi: 10.1128/AEM.71.8.4577-4584.2005.

41. Hu LB, Shi ZQ, Zhang T, Yang ZM. Fengycin antibiotics isolated from B-FS01 culture inhibit the growth of Fusarium moniliforme Sheldon ATCC 38932. FEMS Microbiol Lett. 2007; 272(1):918. doi: 10.1111/j.1574-6968.2007.00743.x.

42. Romero D, de Vicente A, Rakotoaly RH, Dufour SE, Veening JW, Arrebola E, et al. The iturin and fengycin families of lipopeptides are key factors in antagonism of Bacillus subtilis toward Podosphaera fusca. Mol Plant Microbe Interact. 2007; 20(4):430-40. doi: 10.1094/MPMI-20-40430 .

43. Thasana N, Prapagdee B, Rangkadilok N, Sallabhan R, Aye SL, Ruchirawat S, et al. Bacillus subtilis SSE4 produces subtulene A, a new lipopeptide antibiotic possessing an unusual C15 unsaturated beta-amino acid. FEBS Lett. 2010; 584(14):3209-14. doi: 10.1016/j.febslet.2010.06.005.

44. Benitez LB, Velho RV, Lisboa MP, Medina LF, Brandelli A. Isolation and characterization of antifungal peptides produced by Bacillus amyloliquefaciens LBM5006. J Microbiol. 2010; 
48(6):791-7. doi: 10.1007/s12275-010-0164-0.

45. Yánez-Mendizábal V, Zeriouh H, Viñas I, Torres R, Usall J, de Vicente A, et al. Biological control of peach brown rot (Monilinia spp.) by Bacillus subtilis CPA-8 is based on production of fengycin-like lipopeptides. Eur J Plant Pathol. 2011; 132(4): 609-19.

46. Velho RV, Medina LF, Segalin J, Brandelli A. Production of lipopeptides among Bacillus strains showing growth inhibition of phytopathogenic fungi. Folia Microbiol (Praha). 2011; 56(4):297-303. doi: 10.1007/s12223-011-00567.

47. Waewthongrak W, Pisuchpen S, Leelasuphaku W. Effect of Bacillus subtilis and chitosan applications on green mold (Penicilium digitatum Sacc.) decay in citrus fruit. Postharvest Biol Technol. 2015; 99:44-9.

48. Radovanović N, Milutinović M, Mihajlovski K, Jović J, Nastasijević B, Rajilić-Stojanović M, et al. Biocontrol and plant stimulating potential of novel strain Bacillus sp. PPM3 isolated from marine sediment. Microb Pathog. 2018; 120:718. doi: 10.1016/j.micpath.2018.04.056.

49. Adeniji AA, Aremu OS, Babalola OO. Selecting lipopeptide-producing, Fusarium-suppressing Bacillus spp.: metabolomic and genomic probing of Bacillus velezensis NWUMFkBS10.5. Microbiologyopen. 2019; 8(6):e00742. doi: 10.1002/ mbo3.742.

50. Hazarika DJ, Goswami G, Gautom T, Parveen A, Das P, Barooah M, et al. Lipopeptide mediated biocontrol activity of endophytic Bacillus subtilis against fungal phytopathogens. BMC Microbiol. 2019; 19(1):71. doi: 10.1186/s12866-0191440-8

51. Wang Y, Liang J, Zhang C, Wang L, Gao W, Jiang J. Bacillus megaterium WL-3 lipopeptides collaborate against Phytophthora infestans to control potato late blight and promote potato plant growth. Front Microbiol. 2020; 11:1602. doi: 10.3389/fmicb.2020.01602.

52. Pedras MS, Ismail N, Quail JW, Boyetchko SM. Structure, chemistry, and biological activity of pseudophomins A and B, new cyclic lipodepsipeptides isolated from the biocontrol bacterium Pseudomonas fluorescens. Phytochem- istry. 2003; 62(7):1105-14. doi: 10.1016/s00319422(02)00617-9.

53. Mohammadipour M, Mousivand M, Salehi Jouzani G, Abbasalizadeh S. Molecular and biochemical characterization of Iranian surfactin-producing Bacillus subtilis isolates and evaluation of their biocontrol potential against Aspergillus flavus and Colletotrichum gloeosporioides. Can J Microbiol. 2009; 55(4):395-404. doi: 10.1139/w08-141.

54. Tareq FS, Lee MA, Lee HS, Lee JS, Lee YJ, Shin HJ. Gageostatins A-C, antimicrobial linear lipopeptides from a marine Bacillus subtilis. Mar Drugs. 2014;12(2):871-85. doi: 10.3390/ md12020871

55. Singh AK, Rautela R, Cameotra SS. Substrate dependent in vitro antifungal activity of Bacillus sp. strain AR2. Microb Cell Fact. 2014, 13:67. doi: 10.1186/1475-2859-13-67.

56. Mnif I, Hammami I, Triki MA, Azabou MC, Ellouze-Chaabouni S, Ghribi D. Antifungal efficiency of a lipopeptide biosurfactant derived from Bacillus subtilis SPB1 versus the phytopathogenic fungus, Fusarium solani. Environ Sci Pollut Res Int. 2015; 22(22):18137-47. doi: 10.1007/s11356-015-5005-6.

57. Mnif I, Grau-Campistany A, Coronel-León J, Hammami I, Triki MA, Manresa A, et al. Purification and identification of Bacillus subtilis SPB1 lipopeptide biosurfactant exhibiting antifungal activity against Rhizoctonia bataticola and Rhizoctonia solani. Environ Sci Pollut Res Int. 2016; 23(7):6690-9. doi: 10.1007/s11356015-5826-3.

58. Zhang L, Sun C. Fengycins, cyclic lipopeptides from marine Bacillus subtilis strains, kill the plant-pathogenic fungus Magnaporthe grisea by inducing reactive oxygen species production and chromatin condensation. Appl Environ Microbiol. 2018; 84(18):e00445-18. doi: 10.1128/ AEM.00445-18.

59. Wu S, Liu G, Zhou S, Sha Z, Sun C. Characterization of antifungal lipopeptide biosurfactants produced by marine bacterium Bacillus sp. CS30. Mar Drugs. 2019; 17(4):199. doi: 10.3390/ md17040199. 
60. Castro D, Torres M, Sampedro I, Martínez-Checa F, Torres B, Béjar V. Biological control of Verticillium wilt on olive trees by the salt-tolerant strain Bacillus velezensis XT1. Microorganisms. 2020; 8(7):1080. doi: 10.3390/microorganisms 8071080 .

61. Chakraborty M, Mahmud NU, Gupta DR, Tareq FS, Shin HJ, Islam T. Inhibitory effects of linear lipopeptides from a marine Bacillus subtilis on the wheat blast fungus Magnaporthe oryzae triticum. Front Microbiol. 2020;11:665. doi: 10.3389/fmicb.2020.00665

62. Oni FE, Geudens N, Adiobo A, Omoboye OO, Enow EA, Onyeka JT, et al. Biosynthesis and antimicrobial activity of pseudodesmin and viscosinamide cyclic lipopeptides produced by Pseudomonads associated with the cocoyam rhizosphere. Microorganisms. 2020; 8(7):1079. doi: 10.3390/microorganisms 8071079 .

63. Bais HP, Fall R, Vivanco JM. Biocontrol of $B a$ cillus subtilis against infection of Arabidopsis roots by Pseudomonas syringae is facilitated by biofilm formation and surfactin production. Plant Physiol. 2004; 134(1):307-19. doi: 10.1104/ pp. 103.028712 .

64. Etchegaray A, de Castro Bueno C, de Melo IS, Tsai SM, Fiore MF, Silva-Stenico ME, et al. Effect of a highly concentrated lipopeptide extract of Bacillus subtilis on fungal and bacterial cells. Arch Microbiol. 2008; 190(6):611-22. doi: 10.1007/s00203-008-0409-z.

65. Zeriouh H, Romero D, Garcia-Gutierrez L, Cazorla FM, de Vicente A, Perez-Garcia A. The iturin-like lipopeptides are essential components in the biological control arsenal of Bacillus subtilis against bacterial diseases of cucurbits. Mol Plant Microbe Interact. 2011; 24(12):1540-52. doi: 10.1094/MPMI-06-11-0162.

66. Luo C, Liu X, Zhou X, Guo J, Truong J, Wang X, et al. Unusual biosynthesis and structure of locillomycins from Bacillus subtilis 916. Appl Environ Microbiol. 2015; 81(19):6601-9. doi: 10.1128/AEM.01639-15.

67. Cao Y, Pi H, Chandrangsu P, Li Y, Wang Y, Zhou H, et al. Antagonism of two plant-growth promoting Bacillus velezensis isolates against Ralstonia solanacearum and Fusarium oxyspo- rum. Sci Rep. 2018; 8(1):4360. doi: 10.1038/ s41598-018-22782-z.

68. Abdallah DB, Tounsi S, Gharsallah H, Hammami A, Frikha-Gargouri O. Lipopeptides from $\mathrm{Ba}$ cillus amyloliquefaciens strain $32 \mathrm{a}$ as promising biocontrol compounds against the plant pathogen Agrobacterium tumefaciens. Environ Sci Pollut Res Int. 2018; 25(36):36518-29. doi: 10.1007/ s11356-018-3570-1.

69. Medeot DB, Fernandez M, Morales GM, Jofré E. Fengycins from Bacillus amyloliquefaciens MEP218 exhibit antibacterial activity by producing alterations on the cell surface of the pathogens Xanthomonas axonopodis pv. vesicatoria and Pseudomonas aeruginosa PA01. Front Microbiol. 2020; 10:3107. doi: 10.3389/ fmicb.2019.03107.

70. Chen M, Wang J, Liu B, Zhu Y, Xiao R, Yang W, et al. Biocontrol of tomato bacterial wilt by the new strain Bacillus velezensis FJAT-46737 and its lipopeptides. BMC Microbiol. 2020; 20(1):160. doi: 10.1186/s12866-020-01851-2.

71. Grady EN, MacDonald J, Ho MT, Weselowski B, McDowell T, Solomon O, et al. Characterization and complete genome analysis of the surfactin-producing, plant-protecting bacterium Bacillus velezensis 9D-6. BMC Microbiol. 2019; 19(1):5. doi: 10.1186/s12866-018-1380-8.

72. Pirog TP, Lutsay DA, Kliuchka LV, Beregova KA. Antimicrobial activity of surfactants of microbial origin. Biotechnologia Acta. 2019; 12(1):39-57. https://doi.org/10.15407/biotech12.01.039

73. Pirog TP, Kliuchka LV, Shevchuk TA, Muchnyk FV. [Interrelation of chemical composition and biological properties of microbial surfactants]. Mikrobiol Z. 2019; 81(3):84-104. Ukrainian. doi: https://doi.org/10.15407/microbiolj81.03.084

74. Lang S, Katsiwela E, Wagner F. Antimicrobial effects of biosurfactants. Lipid Fett. 1989; 91: 363-6. doi: 10.1002/lipi.19890910908.

75. Stanghellini ME, Miller RM. Biosurfactants: their identity and potential efficacy in the biological bontrol of zoosporic plant pathogens. Plant Dis. 1997; 81(1):4-12. doi: 10.1094/ PDIS.1997.81.1.4. 
76. Abalos A, Pinazo A, Infante MR, Casals M, Garc1'a F, Manresa A. Physicochemical and antimicrobial properties of new rhamnolipids produced by Pseudomonas aeruginosa AT10 from soybean oil refinery wastes. Langmuir. 2001; 17:1367-71.

77. Haba E, Pinazo A, Jauregui O, Espuny MJ, Infante MR, Manresa A. Physicochemical characterization and antimicrobial properties of rhamnolipids produced by Pseudomonas aeruginosa 47T2 NCBIM 40044. Biotechnol Bioeng. 2003; 81(3):316-22. doi: 10.1002/bit.10474.

78. Benincasa M, Abalos A, Oliveira I, Manresa A. Chemical structure, surface properties and biological activities of the biosurfactant produced by Pseudomonas aeruginosa LBI from soapstock. Antonie Van Leeuwenhoek. 2004; 85(1):1-8. doi: 10.1023/B:ANTO.0000020148.45523.41.

79. Perneel M, D'hondt L, De Maeyer K, Adiobo A, Rabaey K, Höfte M. Phenazines and biosurfactants interact in the biological control of soil-borne diseases caused by Pythium spp. Environ Microbiol. 2008; 10(3):778-88. doi: 10.1111/j.1462-2920.2007.01501.x.

80. Varnier AL, Sanchez L, Vatsa P, Boudesocque L, Garcia-Brugger A, Rabenoelina F, et al. Bacterial rhamnolipids are novel MAMPs conferring resistance to Botrytis cinerea in grapevine. Plant Cell Environ. 2009; 32(2):178-193. doi: 10.1111/j.1365-3040.2008.01911.x.

81. Sha R, Jiang L, Meng Q, Zhang G, Song Z. Producing cell-free culture broth of rhamnolipids as a cost-effective fungicide against plant pathogens. J Basic Microbiol. 2012; 52(4):458-66. doi: 10.1002/jobm.201100295.

82. Goswami D, Handique PJ, Deka S. Rhamnolipid biosurfactant against Fusarium sacchari - the causal organism of pokkah boeng disease of sugarcane. J Basic Microbiol. 2014; 54(6):548--57. doi: 10.1002/jobm.201200801.

83. Nalini S, Parthasarathi R. Production and characterization of rhamnolipids produced by Serratia rubidaea SNAU02 under solid-state fermentation and its application as biocontrol agent. Bioresour Technol. 2014; 173:231-8. doi: 10.1016/j. biortech.2014.09.051.
84. Soltani Dashtbozorg S, Miao S, Ju LK. Rhamnolipids as environmentally friendly biopesticide against plant pathogen Phytophthora sojae. Environ Prog Sustain Energy. 2015; 35(1):169-73. doi:10.1002/ep.12187.

85. Goswami D, Borah SN, Lahkar J, Handique PJ, Deka S. Antifungal properties of rhamnolipid produced by Pseudomonas aeruginosa DS9 against Colletotrichum falcatum. J Basic Microbiol. 2015; 55(11):1265-74. doi: 10.1002/ jobm.201500220.

86. Yan F, Xu S, Guo J, Chen Q, Meng Q, Zheng X. Biocontrol of post-harvest Alternaria alternata decay of cherry tomatoes with rhamnolipids and possible mechanisms of action. J Sci Food Agric. 2015; 95(7):1469-74. doi: 10.1002/jsfa.6845.

87. Sha R, Meng Q. Antifungal activity of rhamnolipids against dimorphic fungi. J Gen Appl Microbiol. 2016; 62(5):233-9. doi: 10.2323/ jgam.2016.04.004.

88. Rodrigues AI, Gudiña EJ, Teixeira JA, Rodrigues LR. Sodium chloride effect on the aggregation behaviour of rhamnolipids and their antifungal activity. Sci Rep. 2017; 7(1):12907. doi: 10.1038/s41598-017-13424-x.

89. Monnier N, Furlan A, Botcazon C, Dahi A, Mongelard G, Cordelier S, et al. Rhamnolipids from Pseudomonas aeruginosa are elicitors triggering Brassica napus protection against Botrytis cinerea without physiological disorders. Front Plant Sci. 2018; 9:1170. doi: 10.3389/fpls.2018.01170

90. Monnier N, Cordier M, Dahi A, Santoni V, Guénin $\mathrm{S}$, Clément $\mathrm{C}$, et al. Semipurified rhamnolipid mixes protect Brassica napus against Leptosphaeria maculans early infections. Phytopathology. 2020; 110(4):834-42. doi: 10.1094/PHYTO-07-19-0275-R.

91. Kim BS, Lee JY, Hwang BK. In vivo control and in vitro antifungal activity of rhamnolipid $\mathrm{B}$, a glycolipid antibiotic, against Phytophthora capsici and Colletotrichum orbiculare. Pest Manag Sci. 2000; 56(12):1029-35.

92. Leite GG, Figueirôa JV, Almeida TC, Valões JL, Marques WF, Duarte MD, et al. Production of rhamnolipids and diesel oil degradation by bacteria isolated from soil contaminated by petro- 
leum. Biotechnol Prog. 2016; 32(2):262-70. doi: 10.1002/btpr.2208.

93. Clements T, Ndlovu T, Khan S, Khan W. Biosurfactants produced by Serratia species: classification, biosynthesis, production and application. Appl Microbiol Biotechnol. 2019; 103(2):589602. doi: 10.1007/s00253-018-9520-5.

94. Kim K, Yoo D, Kim Y, Lee B, Shin D, Kim EK. Characteristics of sophorolipid as an antimicrobial agent. J Microbiol Biotechnol. 2002; 12(2): 235-41.

95. Yoo DS, Lee BS, Kim EK. Characteristics of microbial biosurfactant as an antifungal agent against plant pathogenic fungus. J Microbiol Biotechnol 2005; 15:1164-9.

96. Yuan B, Yang S, Chen J. Antimicrobial activity of sophorolipids on pathogenic fungi isolated from fruits. Chin J Appl Environ Biol. 2011; 17(3):330-3.
97. Schofield MH, Thavasi R, Gross RA. Modified sophorolipids for the inhibition of plant pathogens. US Patent: 20130085067 A1. Publ. 04.04.2013.

98. Pirog TP, Konon AD, Sofilkanich AP, Iutinskaia GA. Effect of surface-active substances of Acinetobacter calcoaceticus IMV B-7241, Rhodococcus erythropolis IMV Ac-5017, and Nocardia vaccinii K-8 on phytopathogenic bacteria. Appl Biochem Microbiol. 2013; 49(4):360-7. doi:10.1134/S000368381304011X.

99. Gong Z, Yang G, Che C, Liu J, Si M, He Q. Foaming of rhamnolipids fermentation: impact factors and fermentation strategies. Microb Cell Fact. 2021; 20(1):77. doi: 10.1186/s12934-02101516-3.

100. Rangarajan V, Clarke KG. Process development and intensification for enhanced production of Bacillus lipopeptides. Biotechnol Genet Eng Rev. 2015; 31(1-2):46-68. doi: $10.1080 / 02648725.2016 .1166335$

Received 25.07.2021 